\title{
Groundwater quality assessment for drinking and irrigation purpose using GIS, Piper diagram, and water quality index \\ https://doi.org/10.21698/rjeec.2020.214 \\ Proceedings Paper
}

\author{
NICOLETA VASILACHE ${ }^{1,2}$, ELENA DIACU ${ }^{2}$, GABRIELA GEANINA VASILE $^{1}$, CRISTINA $^{2}$ \\ MODROGAN $^{2}$, IULIANA CLAUDIA PAUN ${ }^{1}$, FLORINELA PIRVU $^{1}$

\begin{abstract}
${ }^{1}$ National Research and Development Institute for Industrial Ecology - ECOIND, 71-73 Drumul Podu Dambovitei, Sector 6, 060652, Bucharest, Romania

${ }^{2}$ University Politehnica of Bucharest, Faculty of Applied Chemistry and Materials Science, 1-7 Polizu, Bucharest, 011061, Romania

*Corresponding author (e-mail): nicoleta.vasilache@incdecoind.ro
\end{abstract}

\begin{abstract}
The chemical behavior of groundwater is one of the most dynamic areas of environmental research. In the present study, groundwater sampling from different locations in the central and south-eastern parts of Romania was performed to assess groundwater chemistry and to compare water types using distribution maps. Groundwater chemistry has been evaluated and natural processes are identified as control factors for hydrochemistry. The Piper diagram was created to compare the results of water types. Chemical analysis of groundwater was used to calculate the values of the water quality index. Romanian drinking water Law EPA 458-2002 and WHO standards were taken into account when calculating the WQI. The SAR index was used to evaluate groundwater samples, taken from in the study area, and used for irrigation purposes. The classification of water types based on water quality (WQI) values for each groundwater sample shows that $80 \%$ of the analyzed samples can be used as drinking water resources, the rest of $20 \%$ being intended for irrigation.
\end{abstract}

Keywords: groundwater, distribution map, Piper diagram, sodium adsorption ratio, water quality index

\section{INTRODUCTION}

Groundwater comes in the form of rain or snow that seeps through the soil into the flow systems of basic geological materials. The soil area has unique and strong abilities to change the chemistry of water because infiltration occurs through this thin biologically active area. In recharge areas, the soil suffers a net loss of minerals in the flowing water. As groundwater moves along flows from recharge to discharge areas, the effects of a variety of geochemical processes alter its chemistry. Water type assessment is extremely useful to provide a preliminary idea of complex hydrochemical processes. Groundwater chemistry is influenced by many factors including precipitation, the structure of river basins and aquifers, climate and topography as well as anthropogenic influence such as urban, industrial, and agricultural activities $[1,2]$. The combination of these factors creates various types of water that change their spatial and temporal evolution. When water percolates through formations, it is exposed to geologic formations and ions are exchanged especially during the process of weathering and alteration. These rocks release minerals whose ions enter aquifers and alter the chemical composition.

The purpose of this study was to evaluate groundwater sources in different locations in Romania, to determine their use as drinking water or for irrigation, using the Piper diagram and WQI index [3, 4]. A variety of methods have been used successfully in recent years to assess groundwater chemistry, providing an overview of water quality and a result that describes the state of groundwater.

\section{MATERIALS AND METHODS}

\section{The study area}

The samples on the study area are located in the central and south-eastern parts of Romania. The hydrographic and hydrological peculiarities of
Romania are determined, mainly, by the geographical position of the country in the area of temperate-continental climate and by the 
presence of the Carpathian arc. The anthropogenic factor contributes to some changes in these characteristics. The study area mostly covers the area of the Muntenia region and partially the area of Transylvania and Moldova.
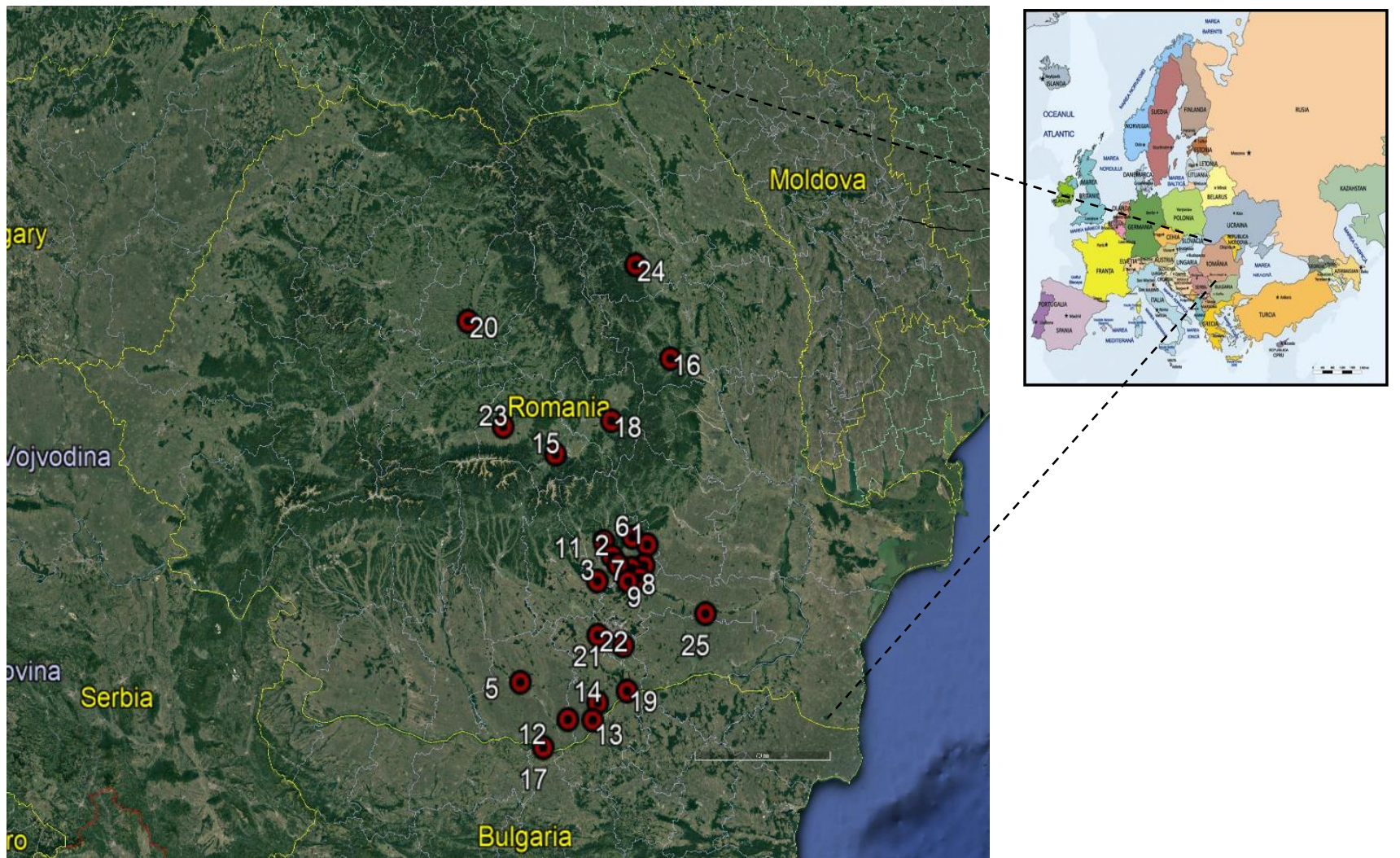

Fig. 1. The study area

Romania has a temperate continental climate of transition, specific to Central Europe, with four distinct seasons, spring, summer, autumn, and winter. The local climatic differences are due to several altitudes and latitudes, respectively more oceanic influences from the west, the Mediterranean from the south of the west, and the continental ones from the east. In the hilly area, the soils are suitable for cultivating fruit trees, vines.

Twenty-five samples were collected from water wells distributed throughout the study area. The locations of these areas are shown in Fig. 1. The electrical conductivity (EC) parameter was measured using the electrochemical technique. Anions and cations were measured in all groundwater in the laboratory. $\mathrm{Ca}^{2+}, \mathrm{Na}^{+}, \mathrm{K}^{+}$, and $\mathrm{Mg}^{2+}$ were analyzed by the ICP-OES method. $\mathrm{Cl}^{-}, \mathrm{HCO}_{3}^{-}$by volumetric technique, $\mathrm{SO}_{4}{ }^{2-}$ by turbidimetric method, total dissolved solids (TDS) by gravimetric technique, $\mathrm{NO}_{3}{ }^{-}$

$$
\mathbf{S A R}=\frac{N a^{+}}{\sqrt{\frac{C a^{2+}+M g^{2+}}{2}}}
$$

and $\mathrm{NH}_{4}{ }^{+}$by spectrophotometric technique. All measured values were used to create Spatial distribution maps, the Piper diagram, and to calculate the water quality index values, WQI. The ratio between the sum of anions and cations $\left(\frac{\sum \text { anions }}{\sum \text { cations }}\right)$ is an indicator of the correlation of the measured parameters [5]. Electrical conductivity assesses the level of salinity in the water, as it reflects the total solids dissolved in groundwater, which, when the concentration increases above the imposed limits, causes hazards to crops. Excess salinity in the water reduces the osmotic activity of plants by interfering with the absorption of water and nutrients from the soil. SAR, the sodium adsorption ratio index, is an important parameter to determine the use of groundwater for irrigation purposes. SAR is defined by the following equation: 
The concentrations of the anions and cations are expressed in meq/L. Depending on the value of the sodium adsorption ratio (calculated based on the recorded concentrations for sodium, calcium, and magnesium) and the sodium content in the analyzed waters, they can be classified into salinity classes and alkalization subclasses: subclass $S_{1}$ (reduced alkalization), usable in most soils; subclass $\mathrm{S}_{2}$ (moderate alkalization), usable on permeable soils, without special washing and drainage arrangements; subclass $\mathrm{S}_{3}$ (high alkalization), usable for permeable soils with special arrangements for washing and drainage, as well as with the application of organic and mineral modifications (Table 1), [6, 7].

Table 1. Classification of groundwater for irrigation purposes (salinity classes)

\begin{tabular}{ccccccccccccc}
\hline & \multicolumn{10}{c}{ Salinity classes } \\
Indicator name & \multicolumn{10}{c}{$\mathrm{C}_{1}$} & \multicolumn{1}{c}{$\mathrm{C}_{2}$} & \multicolumn{1}{c}{$\mathrm{C}_{3}$} \\
\cline { 2 - 13 } & $\mathrm{S}_{1}$ & $\mathrm{~S}_{2}$ & $\mathrm{~S}_{3}$ & $\mathrm{~S}_{1}$ & $\mathrm{~S}_{2}$ & $\mathrm{~S}_{3}$ & $\mathrm{~S}_{1}$ & $\mathrm{~S}_{2}$ & $\mathrm{~S}_{3}$ & $\mathrm{~S}_{1}$ & $\mathrm{~S}_{2}$ & $\mathrm{~S}_{3}$ \\
\hline $\begin{array}{c}\text { Index SAR } \\
\left(\mathrm{Na}^{+}, \mathrm{Ca}^{2+}, \mathrm{Mg}^{2+}\right) \\
{[\text { max.] }}\end{array}$ & 8.20 & 15.3 & 22.5 & 6.10 & 12.2 & 18.3 & 4.00 & 9.00 & 14.0 & 2.50 & 6.70 & 11.0 \\
\hline
\end{tabular}

\section{Distribution maps}

Distribution maps by surface interpolation for $\mathrm{NO}_{3}{ }^{-}, \mathrm{SO}_{4}{ }^{2-}, \mathrm{HCO}_{3}{ }^{-}, \mathrm{Cl}^{-}, \mathrm{Ca}^{2+}, \mathrm{Na}^{+}$parameters were made to visualize how the concentration of parameters with an impact on groundwater quality in the studied area varies. Spatial interpolation is one of the many tools in GIS that is used to predict values for any geographic data of points: elevation, precipitation, chemical concentrations, noise levels, etc. The inverse distance weighted method (IDW) was used to interpolate the water quality in the study area. IDW is used to predict a value for an

$$
Z=\frac{\sum_{i=1}^{n} \frac{z_{i}}{h_{i j}^{\beta}}}{\sum_{i=1}^{n} \frac{1}{h_{i j}^{\beta}}}
$$

where $Z$ is the interpolated value, $n$ - the number of values of the data sample, $Z_{i}$ - i-th value, $h_{i j}$ - the separation distance between the interpolated value and the data value, and $\beta$ the weighting power. The optimal weighting

\section{Piper diagram}

Various methods have been used in the chemical evaluation of groundwater for several decades. The first attempt in this direction was made by Hilly (1940), modified by Piper (1944) and improved by Durov (1948) [11]. This method can provide sufficient information on the chemical quality of the water, in particular its origin. The Piper scheme was designed so immeasurable location and values around the prediction point. The values closest to the prediction location will have a greater influence on the predicted value than the farthest ones. The measurement of each point has a local influence that decreases with distance. Those measured values closest to the prediction location will have more influence on the predicted value than those farther away, so, the measurement of each point has a local influence that diminishes with distance. Mathematically, the process is described by equation 2 :

power depends on the spatial structure of the data [8-10]. The distribution maps were made with ArcGIS Map 10.5 and statistical analysis with XLSTAT2020.

that milliequivalent percentages of major cations and anions are drawn in a separate triangle. These points represented in the triangle fields are projected further into the central diamond field, which gives the general character of the water. A Piper diagram is a graphical representation of the chemistry of water samples in the form of the trilinear 
diagram. Separate ternary plots show the relative abundance of common ions (cations and anions). The Piper diagram is comprised of three components as shown in the image below: The lower-left ternary plot representing cations ( $\mathrm{Mg}, \mathrm{Na}, \mathrm{K}, \mathrm{Ca}$ ); the lower-right ternary plot representing anions $\mathrm{CO}_{3}-\mathrm{HCO}_{3}, \mathrm{SO}_{4}, \mathrm{Cl}, \mathrm{NO}_{3}$ ); and a middle diamond plot, which is a matrix transformation of the two ternary diagrams.

The plots display the relative concentrations of each sample (i.e. sum of cations $=100$ and the

\section{Water Quality Index}

The WQI for the studied drinking water was evaluated by applying the weighted arithmetic index method used by Brown et al. (1972) [13]. WQI is used to determine the composite effect of individual parameters on overall water quality. Eleven important parameters were chosen for the WQI calculation [11]. Chemical analysis of groundwater was used to calculate the water quality index. The Romanian Law on Drinking Water 485-2002 [14] and the Guidelines for Drinking Water Quality of the World Health Organization [15] were taken into sum of anions $=100$ ). The data points in the center diamond are located by extending the points in the lower triangles to the point of intersection in the center plot. The axis values at the top and bottom of the center diamond are 100; the axis values on the left and right side of the center plot are 0 [12]. Diagrammes tools from Roland SIMMLER Laboratoire d'Hydrogeochimie d'Avignon was used to create the Piper diagram.

account in calculating the WQI as was shown in Table 1. $w_{i}$, the weight of each chemical parameter was assigned in depending on its relative importance in the quality of water used as a drinking water resource, it is presented in Table 2. The maximum weight assigned to a parameter that is believed to be of great importance in assessing water quality is five and a minimum weight for a chemical parameter that does not affect the overall water quality is 2 (Table 2).

Table 2. Relative weight $\left(\mathrm{W}_{\mathrm{i}}\right)$ values of the groundwater parameters

\begin{tabular}{c|cccc}
\hline $\begin{array}{c}\text { Chemical } \\
\text { parameters }\end{array}$ & Unit & $\begin{array}{c}\text { Weight } \\
\left(\mathrm{w}_{\mathrm{i}}\right)\end{array}$ & $\begin{array}{c}\text { Relative weight } \\
\left(\mathrm{W}_{\mathrm{i}}\right)\end{array}$ & $\begin{array}{c}\mathrm{S}_{\mathrm{t}} \\
\text { Law 458-2002/ } \\
\text { World Health Organization (WHO) [16] }\end{array}$ \\
\hline TDS & $\mathrm{mg} / \mathrm{L}$ & 4 & 0.121 & $1000^{*}$ \\
Conductivity & $\mu \mathrm{S} / \mathrm{cm}$ & 4 & 0.121 & 2500 \\
$\mathrm{NO}_{3}^{-}$ & $\mathrm{mg} / \mathrm{L}$ & 5 & 0.152 & 50 \\
$\mathrm{SO}_{4}^{2-}$ & $\mathrm{mg} / \mathrm{L}$ & 4 & 0.121 & 250 \\
$\mathrm{Cl}^{-}$ & $\mathrm{mg} / \mathrm{L}$ & 3 & 0.093 & 250 \\
$\mathrm{HCO}_{3}^{-}$ & $\mathrm{mg} / \mathrm{L}$ & 5 & 0.152 & $500^{*}$ \\
$\mathrm{~F}^{-}$ & $\mathrm{mg} / \mathrm{L}$ & 1 & 0.030 & 1.2 \\
$\mathrm{Ca}^{2+}$ & $\mathrm{mg} / \mathrm{L}$ & 2 & 0.060 & $100^{*}$ \\
$\mathrm{Mg}^{2+}$ & $\mathrm{mg} / \mathrm{L}$ & 2 & 0.060 & $50^{*}$ \\
$\mathrm{Na}^{+}$ & $\mathrm{mg} / \mathrm{L}$ & 2 & 0.060 & 200 \\
$\mathrm{~K}^{+}$ & $\mathrm{mg} / \mathrm{L}$ & 1 & 0.030 & $20^{*}$ \\
\hline
\end{tabular}

The highest share is given to the parameter nitrate $\left(\mathrm{NO}_{3}{ }^{-}\right)$because it plays an important role in the quality of drinking water, while a lower weight is attributed to parameters such as magnesium $\mathrm{Mg}^{2+}$, calcium $\mathrm{Ca}^{2+}$ and sodium
$\mathrm{Na}^{+}$because they are not harmful to groundwater quality used for drinking. Calculation of the relative individual weight of each parameter, was performed using the equation:

$$
W_{i}=\frac{w_{i}}{\sum_{i=1}^{n} w_{i}}
$$


where $W_{i}$ - relative weight, $w_{i}$ - the weight of parameters, and $n$ - the number of parameters [17, 18].

The quality assessment scale $\left(q_{i}\right)$ is calculated by dividing each concentration of chemical parameters $\left(C_{i}\right)$ in each water

$$
q_{i}=\frac{c_{i}}{s_{t}}
$$

The sub-index of the parameter $\left(S L_{i}\right)$ is calculated for each chemical parameter using

$$
S L_{i}=W_{i} * q_{i}
$$

WQI has been computed using the following

$$
W Q I=\sum S L_{i}
$$

WQI $<0.5$ indicates that water can be used as a drinking water resource, while a higher value indicates poorer water quality. WQI scores make it possible to classify groundwater for sample by the maximum concentration allowed by the Romanian standards (maximum admitted concentration - MAC) for drinking water $\left(S_{t}\right)$ and the WHO's Guide to Drinking Water Quality, as shown in Table 2 [19-21].

the following equation:

relationship:

human consumption into categories such as excellent, good, poor, very poor, and inadequate (Table 3) [22].

Table 3. Classification of the water quality according to the WQI score

\begin{tabular}{c|c}
\hline Range & Class \\
\hline$<0.5$ & Excellent \\
$0.5-1$ & Good \\
$1-2$ & Poor \\
$2-3$ & Very poor \\
$>3$ & Unsuitable \\
\hline
\end{tabular}

\section{RESULTS AND DISCUSSIONS}

\section{Chemical characteristics of water}

The statistical analysis of the physical and chemical parameters is presented in Table 4. The ratio of the sums of the anions to that of the anions was $1.04 \pm 0.11$. For the set of samples considered in this study, the linear regression of the cation sum relative to the sum of the anions led to a value of $\mathrm{R}^{2}=0.96$, indicating that the data quality was satisfactory.

Table 4. Statistical analysis of physical and chemical and parameters of groundwater samples $(\mathrm{n}=25)$

\begin{tabular}{c|ccccc}
\hline Statistic & Min. & Max. & Range & Mean & St. dev \\
\hline TDS & 325 & 2245 & 1920 & 796 & 85.6 \\
$\mathrm{EC}$ & 479 & 3390 & 2911 & 1162 & 129 \\
$\mathrm{NO}^{-}$ & 0.34 & 220 & 220 & 30.9 & 10.5 \\
$\mathrm{SO}^{2-}$ & 8.10 & 262 & 254 & 105 & 18.7 \\
$\mathrm{HCO}^{-}$ & 253 & 1826 & 1573 & 508 & 72.1 \\
$\mathrm{Cl}^{-}$ & 5.68 & 426 & 420 & 94.5 & 23.1 \\
$\mathrm{~F}^{-}$ & 0.07 & 0.40 & 0.33 & 0.19 & 0.02 \\
$\mathrm{Na}^{+}$ & 6.63 & 611 & 604 & 101 & 23.4 \\
$\mathrm{~K}^{+}$ & 0.03 & 47.3 & 47.3 & 3.84 & 114 \\
$\mathrm{Ca}^{2+}$ & 13.0 & 310 & 297 & 34.1 & 1.85 \\
$\mathrm{Mg}^{2+}$ & 4.56 & 100 & 95.4 & 2.69 & 5.17 \\
$\mathrm{SAR}$ & 0.08 & 12.1 & 12.0 & & 0.54 \\
\hline
\end{tabular}

All unit: mg/L (except EC- $\mu \mathrm{S} / \mathrm{cm}, \mathrm{SAR})$ 
The electrical conductivity (EC) of groundwater in the study area varies between $479 \div 3390$ $\mu \mathrm{S} / \mathrm{cm}$, with an average value of $1162 \pm 129$ $\mu \mathrm{S} / \mathrm{cm}$ at $25^{\circ} \mathrm{C}$. Only one sample showed the exceedance of the concentration allowed by the drinking water law of $2500 \mu \mathrm{S} / \mathrm{cm}$. The high conductivity of the water samples corresponds to the high concentrations of dominant ions, resulting from the ion exchange and the solubility of the rocks in the aquifer. All TDS values of groundwater are within the allowable limit of drinking water standards, except for $8 \%$ with values between $1240 \div 2245 \mathrm{mg} / \mathrm{L}$. An increase in TDS values may be due to periods of low rainfall or low soil moisture. Anions such as nitrate, sulfate, chloride, and bicarbonates were the main inorganic components that affected the quality of drinking water in groundwater. $\mathrm{NO}_{3}^{-}$concentrations averaged $30.9 \pm 10.5 \mathrm{mg} / \mathrm{L}$ with an excess of $20 \%(65 \div 220 \mathrm{mg} / \mathrm{L}) . \mathrm{HCO}_{3}{ }^{-}$concentrations

\section{Distribution maps}

The nitrate content of groundwater is distributed in a heterogeneous manner in the study area (Fig. 1). Sample areas with high nitrate concentrations are associated with agricultural activities, recognized as potential sources of nitrate pollution due to the widespread application of inorganic fertilizers. Nitrate concentrations higher than the permitted levels are spatially associated with high concentrations of sulfate and chloride (Fig. 1). This suggests that the origin of nitrates could be associated with non-agricultural sources, such

\section{Drinking and Irrigation Water Quality}

A Piper diagram (Fig. 3) was created for the studied area using the analytical data obtained from the physico-chemical analyzes. In the construction process of the diagram there are 6 fields with different types in which only certain parameters are dominated: $\mathrm{Ca}, \mathrm{Mg}, \mathrm{Na}-\mathrm{K}, \mathrm{Cl}-$ $\mathrm{NO}_{3}, \mathrm{HCO}_{3}-\mathrm{CO}_{3}, \mathrm{SO}_{4}$. The ionic concentrations of the major elements present in groundwater were analyzed for relative abundances and ionic affinity. Graph of the ionic abundance of alkalis with $\mathrm{Na}+\mathrm{K}$ suggests trends in mixture concentrations. Approximately $32 \%$ of the total samples have higher $\mathrm{Ca}$ concentrations than the alkaline ones, in $20 \%$ they have an abundance of $\mathrm{Na}-\mathrm{K}$, the rest of the samples do not have a were exceeded by $32 \%$, with values between $505 \div 1473 \mathrm{mg} / \mathrm{L}$. The concentrations of $\mathrm{Cl}^{-}$and $\mathrm{SO}_{4}{ }^{2-}$, showed an average of $94.5 \pm 23.1 \mathrm{mg} / \mathrm{L}$ and $105 \pm 18.7 \mathrm{mg} / \mathrm{L}$, respectively, with exceedances in $16 \%$ and $8 \%$ of the analyzed groundwater samples. $\mathrm{Ca}^{2+}$ levels ranged from $13 \div 310 \mathrm{mg} / \mathrm{L}$, with a mean value of $114 \pm$ $16.4 \mathrm{mg} / \mathrm{L}$. The sodium concentration in the water samples varies between $6.63 \div 611 \mathrm{mg} / \mathrm{L}$. The high concentration of sodium can result from the infiltration of wastewater and the use of fertilizers in agricultural activities around water sources. The decrease in sodium concentrations during periods of high rainfall reflects the dilution of groundwater by rainwater. Sodium ion makes a relatively average contribution compared to calcium and magnesium. Concentrations of $\mathrm{F}^{-}, \mathrm{Mg}^{2+}$, and $\mathrm{K}^{+}$ ions did not exceed the values required by the standards.

as urban or industrial waste or waste from other anthropogenic activities. Samples with high bicarbonate values are spatially correlated with the values of sodium (Fig. 2) and chlorine (Fig. 1) concentration in the analyzed groundwater, providing data on their salinity level. The spatial distribution map of calcium has a poor correlation with the other parameters. The high values of calcium (Fig. 2) concentrations in groundwater are due to the process of dissociation of calcium from rocks and sedimentary carbonate soils.

dominant type. This type of water could have been derived from groundwater recharge, irrigation return flow, and ion exchange process. The predominance of $\mathrm{Ca}$ over $\mathrm{Na}-\mathrm{K}$ is an indicative ion-exchange reaction due to the structure of the aquifer. The relative abundance of anions was examined, wherein $64 \%$ of the groundwater samples $\mathrm{Cl}-\mathrm{SO}_{4}-\mathrm{NO}_{3}$ is less abundant than $\mathrm{HCO}_{3}$, the concentration of weak acids that exceeds that of strong acids. In the remaining $36 \%$, water has a dominant type of chloride, in which the concentration of weak acids is exceeded by that of strong acids. Given that the dominant type of chloride water is less common in the crystalline groundwater aquifer, 
the source of chloride in groundwater chemistry is unlikely to be evaporation. The increase in concentration in the cases of samples with exceeded nitrate values deduces that the two anions come from the same source, probably from anthropogenic activities.
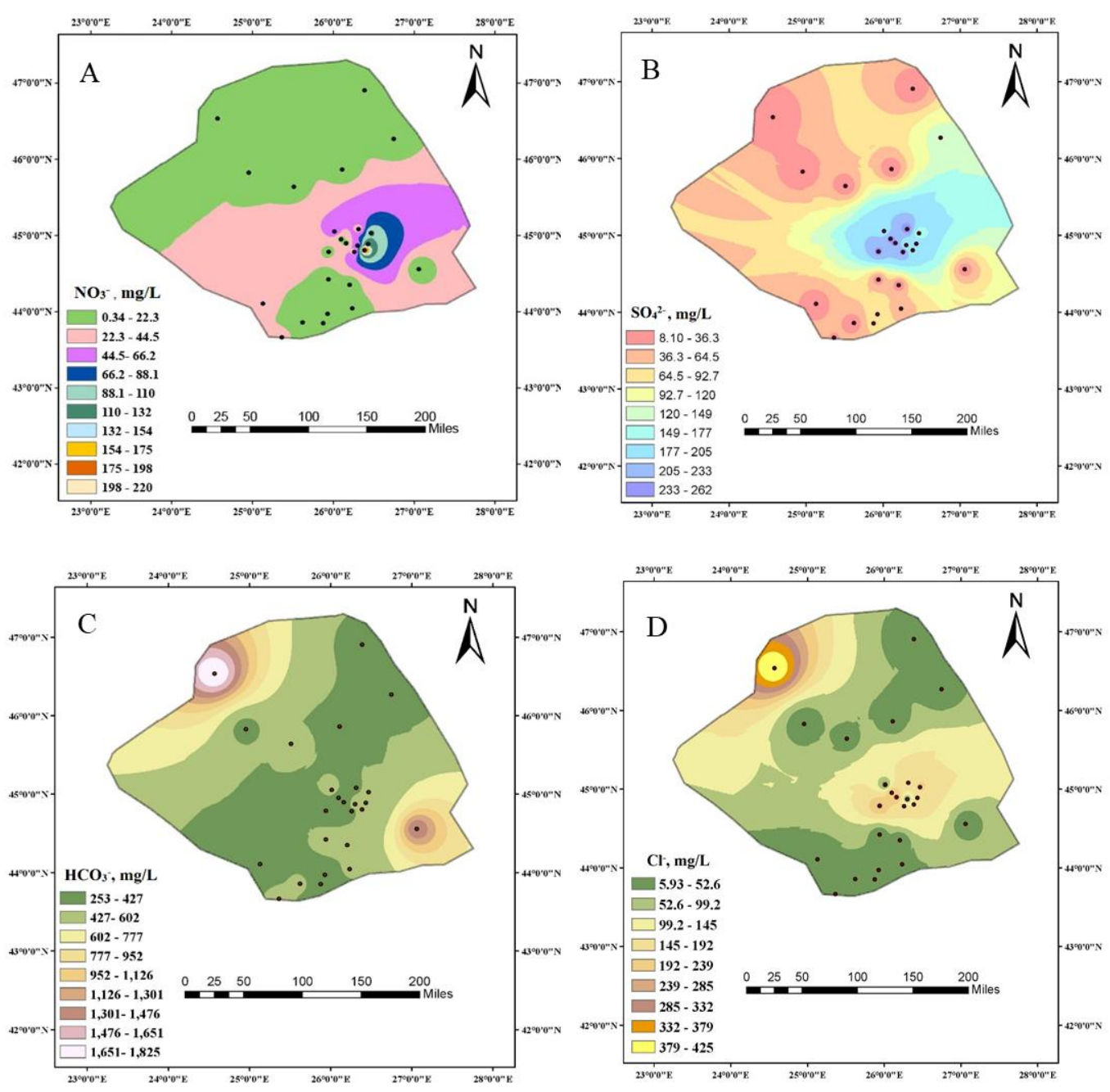

Fig. 1. Spatial distribution map of chemical parameters:

A- nitrate, B- sulfate, C - bicarbonate, D - chloride

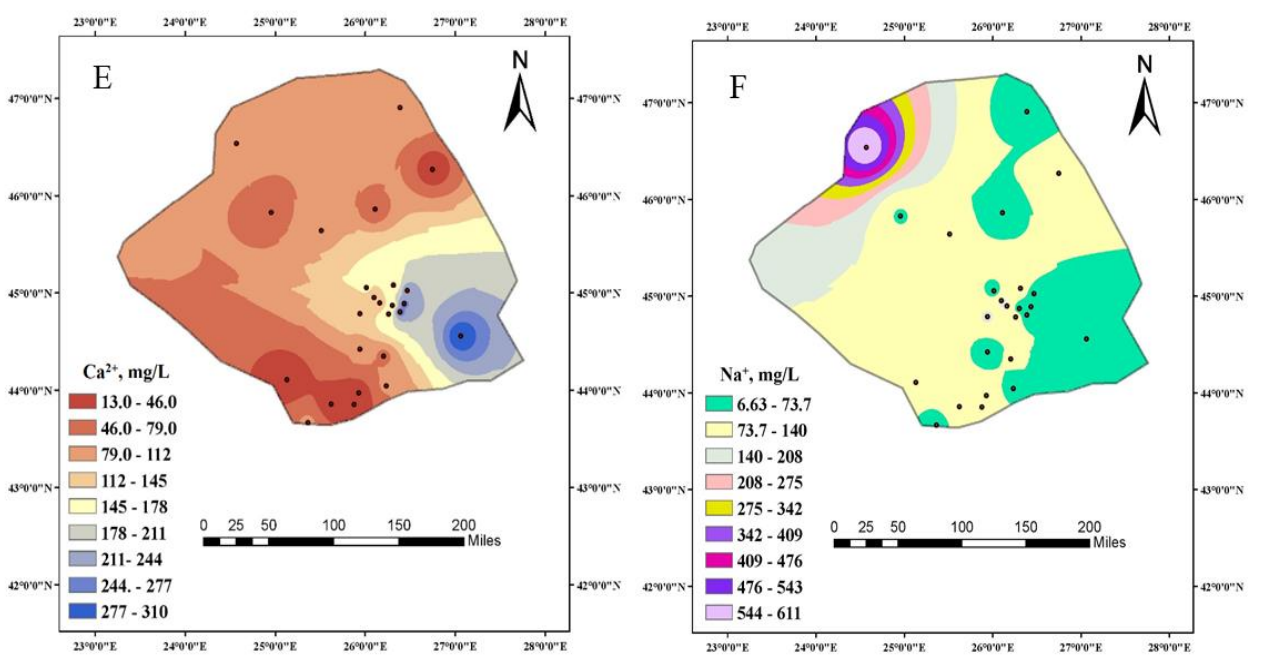

Fig. 2. Spatial distribution map of chemical parameters:

E - calcium, F- sodium in groundwater samples 


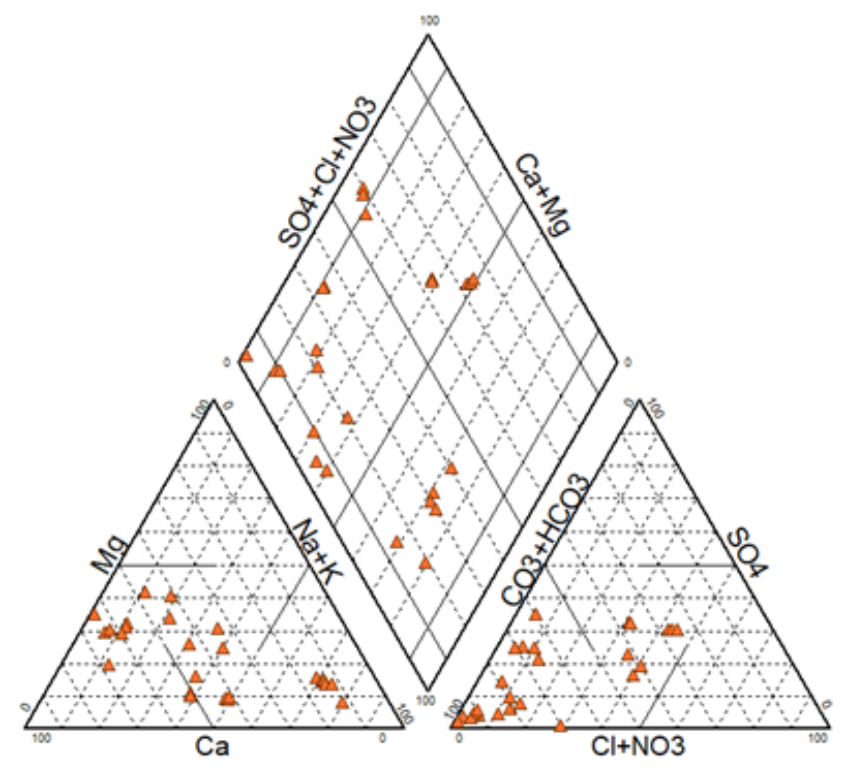

Fig. 3. Piper diagram of groundwater samples in studied area (values in $\%$ meq/L)

Groundwater quality was assessed for irrigation use by determining SAR initiation. The SAR values for the analyzed samples vary from 0.08 to 12.09 with an average of $12.01 \pm 2.69 .83 \%$ of the groundwater samples in the study area fall into the class of low sodium level $\left(\mathrm{S}_{1}\right)$ and can be used for irrigation in most types of soil and $17 \%$ fall into the class of moderate alkalization $\left(\mathrm{S}_{2}\right)$ usable on permeable soils.

Table 5. Classification of water types based on WQI values for each groundwater sample

\begin{tabular}{|c|c|c|c|c|c|}
\hline $\begin{array}{c}\text { Number } \\
\text { sample }\end{array}$ & WQI & $\begin{array}{l}\text { Water } \\
\text { quality }\end{array}$ & $\begin{array}{c}\text { Number } \\
\text { sample }\end{array}$ & WQI & $\begin{array}{l}\text { Water } \\
\text { quality }\end{array}$ \\
\hline 1 & 1.17 & poor water & 14 & 0.31 & excellent water \\
\hline 2 & 0.68 & good water & 15 & 0.40 & excellent water \\
\hline 3 & 0.66 & good water & 16 & 0.34 & excellent water \\
\hline 4 & 0.67 & good water & 17 & 0.51 & good water \\
\hline 5 & 0.29 & excellent water & 18 & 0.27 & excellent water \\
\hline 6 & 0.73 & good water & 19 & 0.40 & good water \\
\hline 7 & 0.73 & good water & 20 & 1.57 & poor water \\
\hline 8 & 1.49 & poor water & 21 & 0.40 & excellent water \\
\hline 9 & 1.22 & poor water & 22 & 0.40 & excellent water \\
\hline 10 & 0.69 & good water & 23 & 0.29 & excellent water \\
\hline 11 & 0.73 & good water & 24 & 0.33 & excellent water \\
\hline 12 & 0.35 & excellent water & 25 & 1.03 & poor water \\
\hline 13 & 0.27 & excellent water & & & \\
\hline
\end{tabular}

WQI values were classified into five types, namely excellent to unsuitable water for drinking, as indicated in Table 5. Based on the classification, only $44 \%$ of groundwater samples fall into class 1 as excellent water, which represents good water quality, $36 \%$ of available water wells fall into class 2 which indicates good water quality, and $20 \%$ of water samples fall into class 3 which indicates a poor water quality can be used for irrigation.

\section{CONCLUSIONS}

Physical-chemical analysis of groundwater revealed that about $16 \%$ of the samples had higher nitrate content. Approximately 20\% had
TDS concentrations higher than $1000 \mathrm{mg} / \mathrm{L}$. Chloride concentrations also exceeded standard levels in $16 \%$ of groundwater samples. Spatial 
distribution maps confirm the correlations between the parameters with the highest weight on water quality. The same correlations were confirmed by the results obtained by creating the Piper diagram. $\mathrm{NO}_{3}{ }^{-}, \mathrm{HCO}^{3-}, \mathrm{Cl}^{-}$and $\mathrm{SO}_{4}{ }^{2-}$ ions have the highest weight in the groundwater pollution process and as a percentage of $20 \%$ of groundwater samples have moderate salinity. They can be used for irrigating permeable soils. The WQI model revealed that $80 \%$ of the samples are suitable for drinking. The

\section{REFERENCES}

1. KURA, N., U., RAMLI, M., F., SULAIMAN, W., N., A., IBRAHIM, S., ARIS, A., Z., MUSTAFA, A., T., Int. J. Environ. Res. Public Health, 10, 2013, p.1861.

2. HE, S., WU, J., Exposure Health, 11, no. 2, 2019, p. 125.

3. PIRVU, F., CRUCERU, L., NICULESCU, M., PETRE, J., IANCU, V., I., PASCU, L., F., GALAON, T., 22 ${ }^{\text {nd }}$ International Symposium "The Environment and the Industry", Bucharest, Romania, 26-27 September 2019, p. 3, http://doi.org/10.21698/simi.2019.fp38.

4. PAUN, I., CHIRIAC, F., L., MARIN, M., N., CRUCERU, L., V., PASCU, L., F., LEHR, B., ENE, C., Rev. Chim., 68, no. 8, 2017, p. 1732.

5. MOULI, P., C., VENKATA, M., S., REDDY, S., J., Atmos. Environ., 39, 2005, p. 6175.

6 YILDIZ, S., KARAKUS, C., B., Environ. Dev. Sustain., 22, 2020, p. 4771.

7. STAS 9450-88: Water for irrigation of agricultural crops, ASRO, https://magazin.asro.ro/Search?q=9450 [in Romanian].

8. BUCHANAN, S., TRIANTAFILIS, J., Ground water, 47, no. 1, 2009, p. 80.

9. GONG, G., MATTEVADA, S., O' BRYANT, S., E., Environ. Res., 130, 2014, p. 59.

10. KIMLEANG, C., SOK, T., CHAN, R., BUNMANUT, H., $2^{\text {nd }}$ International Symposium on Conservation and Management of Tropical Lakes, Siem Reap, Cambodia 24-26 August 2017, p. 5. application of the WQI model, the SAR index, and the interpolated GIS maps for different physical-chemical parameters indicated the potential for groundwater contamination in most areas of the district with a high risk to human health. The final results of physicalchemical and statistical analyses in groundwater suggest monitoring and managing their vulnerability to mitigate the negative impact on human health in the study area.

11. KUMAR, P., J., S., Elixir Geoscience, 54, 2013, p. 12208.

12. WOTCHOKO, P., TITA, M., A., KOUANKAP., N., G., D., ALICE, M., NKEMNJI, J., Z., GUEDJEO, C., S., KAMGANG, K., V., American Journal of Water Resources., 4, no.5, 2016, p. 111.

13. SEIFI, A., DEHGHANI, M., SINGH, V., P., Ecol. Indic., 117, 2020, https://doi.org/10.1016/j.ecolind.2020.106653.

14. Al-PARUANY, K., B., Jordan Journal of Earth and Environmental Sciences, 9, no. 3, 2018, p.153.

15. Law 458-2002 regarding drinking water quality [in Romanian].

16. WHO, World Health organization, Guidelines for Drinking Water Quality, 3rd Edition, Geneva.

17. TALALAJ, I., A., J. Water Chem. Technol., 36, no. 3, 2014, p. 144.

18. VINOD, J., SWAPNIL, D., GUPTA, S., Int. J. Chem Tech Res., 5, no. 1, 2013, p. 278.

19. FATHI, E., RASOOL, Z., A., RAFAT, Z., B., Appl. Water Sci., 8, 2018, https://doi.org/10.1007/s13201-018-0859-7.

20. ACHARAYA, S., SHARMA, S., K., Data in Brief, 2018, p. 928.

21. EL BABA, M., KAYASTHA, P., HUYSMANS, M., DE SMEDT, F., Water J., 12, no. 1,2020 , p. 262

22. SOLANGI, G., S., SIYAL, A., A., BABAR, M., M., SIYAL, P., Hum. Ecol. Risk Assess, 26, 2019, p. 1529. 